\title{
Respiratory Viruses, Eosinophilia and Their Roles in Childhood Asthma
}

\author{
Zak Callaway Chang-Keun Kim \\ Department of Pediatrics, Asthma and Allergy Center, Inje University Sanggye Paik Hospital, Seoul, Korea
}

\section{Key Words}

Asthma $\cdot$ Respiratory virus • Wheezing $\cdot$ Eosinophilia

Respiratory syncytial virus · Eosinophil-derived neurotoxin

\begin{abstract}
With the advent of highly sensitive and specific screening of respiratory specimens for viruses, new viruses are discovered, adding to the growing list of those associated with wheezing illness and asthma exacerbations. It is not known whether early childhood infections with these viruses cause asthma, and, if so, what exactly are the pathophysiologic mechanisms behind its development. The current consensus is that respiratory viral infection works together with allergy to produce the immune and physiologic conditions necessary for asthma diasthesis. One link between viruses and asthma may be the eosinophil, a cell that plays a prominent role in asthma and allergy, but can also be found in the body in response to viral infection. In turn, the eosinophil and its associated products may be novel therapeutic targets, or at the very least, used to elucidate the complex pathophysiologic pathways of asthma and other respiratory illnesses. Together or separately, they can be used for diagnosis, treatment and monitoring. Not only symptoms, but also the underlying disease mechanisms must be taken into consideration for the optimal care of a patient.
\end{abstract}

Copyright $\odot 2010$ S. Karger AG, Basel

\section{KARGER}

Fax +41613061234

E-Mail karger@karger.ch

www.karger.com
(C) 2010 S. Karger AG, Basel

$1018-2438 / 11 / 1551-0001 \$ 38.00 / 0$

Accessible online at:

www.karger.com/iaa

\section{Introduction}

There is a dire need to understand the underlying pathophysiology of asthma, including the complex genetic and environmental influences, to develop more effective treatment strategies. Though the role of respiratory viruses in asthma has been extensively studied over the past few decades, many questions remain unanswered. First, of the known viruses, which are the most likely to cause an infection associated with recurrent wheezing/ asthma development? Second, do early childhood infections with respiratory viruses cause asthma or do they merely select those who are predisposed to these infections? Third, if they are a causal factor, what is the immunopathology behind it? In the following sections, the interactions between viral respiratory infections and asthma development/exacerbations will be explored, with an emphasis on those viruses associated with eosinophilia.

\section{Infections in Infancy and Asthma Development}

It is well known that a substantial portion of infants who require hospitalization for bronchiolitis develop asthma by the age of 13 years [1-5]. The importance of an early-life viral infection has been highlighted by studies 
showing that the timing of birth in relation to the winter virus season can increase the risk of developing asthma by the age of 6 years by as much as 30\% [6]. The exact mechanisms and pathophysiologic pathways by which viral infection leads to asthma are not known, and those that have been proposed are subject to intense debate. Risk factors for bronchiolitis include young age (especially $<6$ months), small lung size and exposure to tobacco smoke [7]. Despite the uncertainty, it is generally considered that respiratory viral infection does not work alone but synergistically with respiratory allergy to produce immunologic and physiologic conditions conducive to asthma development.

Respiratory syncytial virus (RSV) has been the main focus of research, and most infants will have had at least 1 infection with RSV by the age of 3 years. This virus is the major cause of bronchiolitis in children $<1$ year of age; consequently, it is considered the most important respiratory tract pathogen of early childhood [8]. No direct interventional studies demonstrating a causal relationship between RSV and asthma have been published to date. However, a long-term study of over 95,000 children found that timing of birth in relation to the winter virus peak (particularly RSV) independently predicted asthma development, with the highest risk estimated for those born 121 days (approx. 4 months) before the peak [6]. In addition, the administration of anti-RSV immune globulin (palivizumab) to children at high risk of chronic airway disease improved lung function and reduced the incidence of asthma and atopy, suggesting that the prevention of RSV infection has long-term effects on respiratory and immunologic parameters relevant to asthma development [9]. In a larger more recent study, palivizumab significantly reduced recurrent wheezing [10]. However, because nearly every child has been infected with RSV at least once, other genetic, environmental and/or developmental factors must also contribute to the epidemiological link with childhood asthma [11].

A number of recent papers have highlighted a possible role of human rhinovirus (HRV) in asthma etiology. $\mathrm{HRV}$ is now recognized as an important cause of wheezing illness; however, it is most often found in asymptomatic infants and children $[12,13]$. The wide variety of illness severity may be due to either host factors (abnormal innate immune responses) [14] or virus strain (more virulent or pathogenic strains) [15]. In comparative studies, children with RV-induced bronchiolitis were older and more atopic [16] and had a more severe disease course in the acute phase [17] than children with RSV-induced bronchiolitis. In the Perth Birth Cohort study, HRV was the most common pathogen associated with an acute respiratory infection in the first year of life followed by RSV [18]. Another study found that wheezing HRV illnesses during the first 3 years of life were associated with a nearly 10 -fold increase in asthma risk at the age of 6 years [19]. In contrast, several studies suggest that HRV infection is not a risk factor for asthma, but may instead reveal children predisposed to asthma due to abnormal lung physiology and/or immune responses [18, 20, 21].

Another virus that has been implicated as a possible cause of wheezing and asthma is human bocavirus $(\mathrm{HBoV})$, a novel parvovirus first isolated in 2005 from the respiratory secretions of patients with pneumonia [22]. However, the link between $\mathrm{HBoV}$ and asthma, or any respiratory disease, has been complicated by the fact that it has a high rate of coinfection [23]. A recent study conducted at Inje University Sanggye Paik Hospital found an association between $\mathrm{HBoV}$ infection and acute wheezing in children [24]. In their epidemiological study on acute wheezing and children, $\mathrm{HBoV}(13.8 \%)$ was the third most frequently found virus after RV (33.3\%) and RSV (13.8\%). Another epidemiological study by Vallet et al. [25] found $\mathrm{HBoV}$ infection to be associated with $13 \%$ of severe asthma exacerbations in children. They suggested that $\mathrm{HBoV}$ could play a major role in acute exacerbations in asthmatic children.

Other viral infections during infancy and early childhood causing lower respiratory infections are also associated with recurrent wheezing and asthma development. These include parainfluenza, influenza $\mathrm{A}$ and human metapneumovirus $[20,26,27]$. In our recent study, we showed that human metapneumovirus infection was associated with recurrent wheezing in children [28].

The question of whether early childhood viral infections cause asthma, or instead cause chronic disease in those with an underlying predisposition to asthma, remains unanswered.

\section{Viruses and Asthma Exacerbations}

It has been estimated that nearly $85 \%$ of asthma exacerbations in children, and nearly $50 \%$ in adults, are a result of viral infections $[29,30]$. Indeed, with the advent of nucleic acid amplification testing (e.g., reverse transcription polymerase chain reaction) and immunoassays, the detection of HRV and other RNA viruses has been enhanced suggesting that HRV may be responsible for a larger proportion of exacerbations than previously thought. In a study by Rakes et al. [31], HRV was the pre- 
dominant pathogen $(71 \%)$ in children aged $2-16$ years presenting to emergency departments with acute wheezing, while only 6\% were positive for RSV. A study of 206 asthmatic children aged 3-18 years found HRV (26\%) as the most common cause of exacerbation [32], while in adults, HRV was again the most common pathogen $(56 \%$ of virus-positive specimens) found in asthma-related acute-care visits [33]. These studies provide strong evidence of an association between respiratory viral infection and asthma exacerbation. However, it is still unclear whether viral infection alone can exacerbate asthma, or if other factors, such as exposure to allergens [34] or air pollution [35], work synergistically to precipitate an attack.

The body's response to an invading pathogen includes the respiratory, immune and nervous systems [36]. Respiratory viral infections during infancy may have acute and long-term effects on lung and immune system development and represent a risk factor for asthma development. When bronchial epithelial cells are infected by a virus (fig. 1), they generate both local and systemic immune responses aimed at clearing the infection. Neural signals are also generated to coordinate inflammation. However, in the asthmatic individual, immune response is altered and bronchial epithelial cells are damaged. A damaged bronchial epithelial lining is more susceptible to penetration by environmental irritants, which can directly stimulate sensory nerves leading to increased histamine release from mast cells and induction of smooth muscle cell contraction (i.e. bronchoconstriction) by released kinins [37]. A number of mediators are released by infected bronchial epithelial cells and play a role in recruiting major inflammatory cells, such as eosinophils, neutrophils and mast cells, though these cells may already be present in asthmatic airways. Eosinophils can be recruited to inflammatory sites by cytokines, most notably the T-helper type 2 (Th2) cell-derived interleukin (IL)-4, IL-5 and IL13, and chemokines CCL5/RANTES and CCL11/eotaxin-1 [38], while neutrophils are most likely recruited by CXCL8/IL- 8 or leukotriene $\mathrm{B}_{4}$ [39]. In turn, mast cells can be activated by eosinophil-derived major basic protein to release a number of mediators [40]. Together, these major inflammatory cells release mediators that can cause airway hyperresponsiveness, airway remodeling (through the action of eosinophils, fibrogenic and growth factors), and airway limitation (bronchoconstriction, mucosal edema, hypersecretion), leading to characteristic asthma exacerbation symptoms (wheeze, dyspnea, cough, chest tightness).

Respiratory Viruses and Childhood Asthma

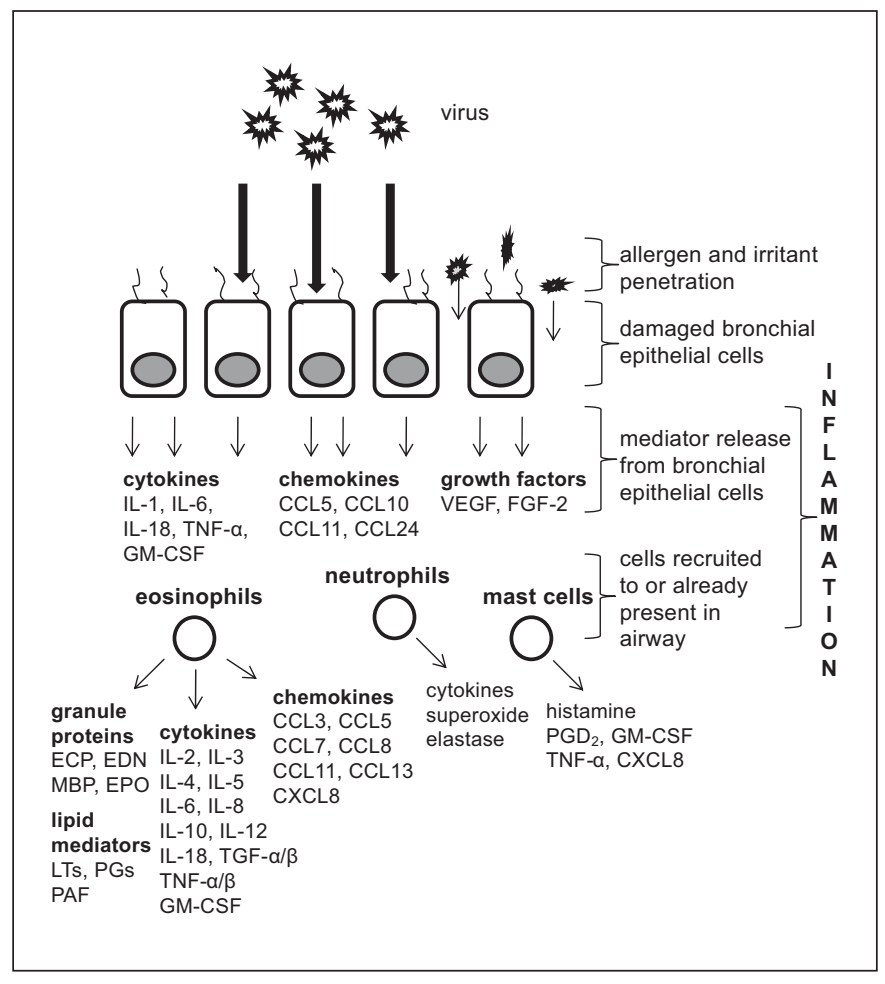

Fig. 1. Viral infection of bronchial epithelial cells leads to release of mediators, including cytokines, chemokines and growth factors. Recruited immune cells (eosinophils, neutrophils and mast cells) release a number of mediators as well. CCL $=\mathrm{CC}$ chemokine ligand; $\mathrm{CXCL}=\mathrm{CXC}$ chemokine ligand; FGF-2 = fibroblast growth factor 2; GM-CSF = granulocyte macrophage colonystimulating factor; $\mathrm{LT}=$ leukotriene; $\mathrm{MBP}=$ major basic protein; $\mathrm{PAF}=$ platelet-activating factor; $\mathrm{PG}=$ prostaglandin; $\mathrm{TNF}=\mathrm{tu}-$ mor necrosis factor; VEGF = vascular endothelial growth factor.

Eosinophils are generally considered as major effector cells of asthma, and it has long been thought that the eosinophilic response to viral infection has a predominantly negative effect on human health, and that it is the major cause of inflammation responsible for tissue damage, bronchoconstriction and respiratory dysfunction [41]. However, several studies have shown that eosinophils may promote viral clearance and antiviral host defense. This concept, termed the 'double-edged sword', was first introduced by Smith [42] in 1994, with respect to the dual role of neutrophils in viral infection. Rosenberg and Domachowske [43-45] followed with their hypothesis that eosinophils may be recruited in part to promote primary antiviral host defense, possibly in situations where acquired immune response was less than effective [46]. More specifically, through their secretory mediators, eo- 
sinophils could reduce the infectivity of RSV for target epithelial cells in vitro. More recently, Phipps et al. [47] demonstrated accelerated clearance of RSV from murine lungs, and that full antiviral activity was dependent on intact Toll-like receptor signaling in eosinophils introduced exogenously.

In the past decade, a new hypothesis regarding asthma pathogenesis has materialized. Through numerous observations it has been noted that lower airway epithelium in asthmatics is structurally and functionally defective. More specifically, this concept incorporates the idea of persistent activation of the epithelium with signaling to the underyling structural cells and has been called the 'epithelial-mesenchymal trophic unit' (EMTU) [48]. This unit could provide a microenvironment conducive to allergic sensitization, lead to different types of inflammation and predispose the airways to exacerbations. Activation of the EMTU may also provide the impetus for tissue remodeling resulting in loss of airway reversibility, reduced lung function and increased resistance to treatment in adults. Together with environmental agents, such as air pollutants, tobacco smoke, drugs and other allergens, viruses can cause epithelial damage through the activation of the EMTU to amplify inflammatory and remodeling responses in the submucosa [49]. Structurally, the epithelium has defective tight junction formation associated with impaired barrier function [50], while functionally, the asthmatic epithelium was more sensitive to oxidant injury [51]. Furthermore, it exhibited profound impairment of virus-induced interferon- $\beta$ mRNA expression and produced $>2.5$ times less interferon- $\beta$ protein in response to respiratory viral infection, culminating in cy totoxic cell death and enhanced viral replication and shedding [52]. However, 2 other recent studies [53, 54] were unable to reproduce these findings. Furthermore, a recent study of viral shedding after experimental HRV-16 inoculation of volunteers with and without asthma found no difference in viral shedding between these 2 groups [55]. In summary, it is still uncertain whether or not a defective epithelium may be at least partially responsible for the numerous chronic inflammatory and structural responses seen in chronic asthma.

\section{Viral Infection and the Hygiene Hypothesis}

Early childhood exposure to certain viruses may actually be protective against atopy and/or asthma, termed the 'hygiene hypothesis' [56]. This highly controversial idea was borne from early observations showing that the risk of developing allergy and/or asthma was inversely related to the number of children in the family [57]. However, this seems paradoxical, as it is also known that bronchiolitis and pneumonia in infancy lead to an increased risk of subsequent asthma. Whether infections have a protective effect or not may have to do with location, frequency, intensity and timing $[58,59]$.

Other environmental factors influence the development of atopic sensitization, including early exposure to pets, increased use of antibiotics and an agricultural background [60]. In an agricultural setting, increased exposure to high levels of endotoxin has been associated with lower rates of allergy and an elevated number of interferon-producing cells in the blood $[61,62]$, cells which are known for their potent anti-viral activity [63]. Taken one step further, Schaub et al. [64] demonstrated that maternal exposure to farming decreases the risk of allergic disease in offspring, possibly through the increased number and activation of T-regulatory cord blood cells associated with lower Th2 cytokine secretion and lymphocyte proliferation on innate exposure. Indeed, there is growing evidence, both in human and animal studies, that pre- and postnatal exposure to pathogens and allergens may provide a protective effect against allergy development. In addition, breastfeeding has been shown to protect against asthma and lower respiratory illness, especially RSV $[65,66]$.

\section{Viral Infection and Atopy}

One paramount question that remains unanswered in determining the link between early childhood infection and asthma development is: do respiratory viral infections merely select those individuals who are predisposed to asthma, or are these infections able to alter lung development/immune response enough to actually cause asthma? A number of studies have shown that respiratory allergy may play a potentially synergistic role with viral infections in producing airway inflammation and subsequent asthma in childhood $[20,58,65]$. One recent cohort study by Kusel et al. [20] only found an association between viral infections during infancy and the subsequent development of persistent wheeze and asthma at the age of 5 years in children with atopic sensitization during the first 2 years of life. This association was also restricted to infections that spread to the lower respiratory tract and were intense enough to cause severe symptoms in the infants. Together, respiratory allergy and infection can cause airway dysfunction through several mechanisms, including viral infection damaging the barrier function 
of the airway epithelium, leading to enhanced absorption of aeroallergens [67], as well as the generation of various cytokines, chemokines, leukotrienes and molecules that may further upregulate cellular recruitment, cell activation and the continuing inflammatory response [37].

\section{The Role of Eosinophilia in Asthma Development/ Exacerbation}

Eosinophilic inflammation is a cardinal feature of asthma, and increases in eosinophilic inflammatory markers have been shown to be good predictors of asthma exacerbations $[68,69]$. It has been demonstrated that suppression of eosinophilic inflammation with glucocorticosteroids is associated with an amelioration of symptoms and airway dysfunction [70]. A recent study by Fanat et al. [71] found that anti-IL-5 treatment reduced the eosinophilopoietic potential of airway smooth muscle cells, suggesting it may promote in situ eosinophilopoiesis in asthmatic lungs. Furthermore, Haldar et al. [72] and Nair et al. [73] demonstrated the ability of anti-IL-5 therapy in reducing eosinophil numbers while improving asthma control in refractory eosinophilic asthma.

\section{Eosinophils as Effector Cells}

Eosinophils are major effector cells of the allergic process. Activation of eosinophils leads to extracellular release of a number of granule proteins, such as eosinophil cationic protein (ECP), eosinophil-derived neurotoxin $(\mathrm{EDN})$, major basic protein and eosinophil peroxidase (EPO) (fig. 1) [74]. Among the many mediators released during eosinophil activation and degranulation, it is these eosinophil granule proteins that are the most strongly implicated in the pathophysiology of asthma [75]. Eosinophils also release a number of proinflammatory cytokines, chemokines and lipid mediators. In addition, eosinophils express a large number of cell surface markers, including adhesion and apoptotic signaling molecules, chemokine, complement and chemotactic factor receptors, and cytokine, immunoglobulin, prostaglandin, platelet-activating factor and leukotriene receptors [76-80].

Eosinophils have generally been regarded as terminal effector cells in allergic airway diseases; however, recent studies demonstrate their involvement in the initial stages of allergic disease development as well [81]. Murine studies suggest that eosinophils may actually drive T-cell responses as opposed to merely being driven by them. Eosinophils can act as antigen-presenting cells [82, 83]; thus, at disease onset, they are able to induce activation and proliferation and/or cytokine production in T cells.

\section{Viral Infection and Eosinophilia}

To further elucidate the connection between early childhood viral infection and asthma development, several studies involving RSV bronchiolitis have been carried out due to the clinical analogy, epidemiologic relationship and similar immunologic phenomena in the airways, such as specific IgE production [84], generation of chemokines [85] and adhesion molecules [86], as well as the eosinophil activation [87] which it shares with childhood asthma. A number of studies have demonstrated eosinophilia during/after RSV bronchiolitis [16, 31, 8791] (table 1). However, the downfall of many RSV studies is the lack of premorbid eosinophil levels. Therefore, it cannot be explicitly stated that the observed eosinophilia was a result of RSV infection. Indeed, prenatal Th2/Th1 imbalance, allergic sensitization during pregnancy or some other reason may result in elevated eosinophil levels in infants. This was suggested in a study by Frischer et al. [92] of neonates born to atopic parents.

Though most viral infections are thought to be neutrophilic in nature, studies by our research group have shown that a subgroup of RSV bronchiolitis patients is eosinophil positive [88]. This subgroup also had higher levels of Th2 cytokines. Eosinophilia together with a skewed Th2 cytokine response strongly resembles the immunologic profile of childhood asthma. To further strengthen the relationship between RSV bronchiolitis and asthma, our research group recently undertook an RSV bronchiolitis study [87] investigating eosinophil degranulation after bronchiolitis and its association with recurrent wheezing. We found good correlations between the eosinophil degranulation marker, EDN, and recurrent wheezing episodes in a cohort of infants with a first episode of RSV bronchiolitis. Furthermore, EDN levels at 3 months proved to have predictive value for recurrent wheezing (positive predictive value $57 \%$, negative predictive value $76 \%$, sensitivity $72 \%$, specificity $62 \%$ ). Indeed, it appears that there is a subgroup of RSV bronchiolitis patients with marked eosinophilia that may go on to later develop asthma. This hypothesis may help elucidate the link between early childhood infections and asthma development.

\section{Asthma Phenotypes}

A number of techniques have recently been used to characterize the myriad of asthma phenotypes in hopes of better tailoring treatment to the individual. The classical IgE-associated allergic asthma phenotype (also termed 
Table 1. RSV bronchiolitis and atopic features

\begin{tabular}{|c|c|c|c|c|c|c|c|}
\hline & \multicolumn{7}{|l|}{ First author } \\
\hline & $\begin{array}{l}\text { Ehlenfield } \\
\text { [89] }\end{array}$ & Kim [88] & $\begin{array}{l}\text { Piippo-Savolainen } \\
\text { [90] }\end{array}$ & Korppi [16] & Kim [87] & Sigurs [91] & Rakes [31] \\
\hline Year of publication & 2000 & 2003 & 2007 & 2004 & 2010 & 1995 & 1999 \\
\hline RSV patients & 43 & 22 & 33 & 24 & 150 & 47 & $15 / 22(68 \%)$ \\
\hline Control group & none & 14 & none & none & 28 & 93 & 17 \\
\hline Age, months & $\begin{array}{l}2-18 \\
\text { (range) }\end{array}$ & $\begin{array}{l}10 \\
\text { (median) }\end{array}$ & $\begin{array}{l}100 \%<24 \\
73 \%<12\end{array}$ & 5 (median) & 14 (mean) & 3.5 (mean) & $2-24$ (range) \\
\hline $\begin{array}{l}\text { Bronchiolitis as 1st } \\
\text { wheezing episode }\end{array}$ & yes & yes & $\begin{array}{l}3(9 \%) \text { had previous } \\
\text { parent-reported } \\
\text { wheezing }\end{array}$ & yes & yes & yes & $\begin{array}{l}15 / 22(68 \%) \text { had a } \\
\text { history of prior } \\
\text { wheezing illness }\end{array}$ \\
\hline \multicolumn{8}{|l|}{ Data on: } \\
\hline Eosinophilia & $\begin{array}{l}16 / 43(37 \%) \\
\text { with Eos } \\
\geq 1 \%\end{array}$ & $\begin{array}{l}6 / 22(27 \%) \\
\text { had Eos } \\
\text { beyond } 2 \\
\text { SD of } \\
\text { normal }\end{array}$ & $\begin{array}{l}0.198 \times 10^{9} / 1 \\
(\text { convalescent phase) } \\
0.046 \times 10^{9} / 1 \text { (acute } \\
\text { phase })\end{array}$ & $\begin{array}{l}2 / 22(9 \%) \text { Eos } \\
\text { count } \geq 0.45 \\
\times 10^{9} / 1\end{array}$ & $\begin{array}{l}\text { elevated compared } \\
\text { with controls }(\mathrm{p}< \\
0.05) ; \text { Eos count } \\
0.180 \times 10^{9} / 1\end{array}$ & no data & $\begin{array}{l}1 / 15(7 \%) \text { had nasal } \\
\text { eosinophilia; } 7 / 15 \\
(47 \%) \text { had elevated } \\
\text { nasal ECP levels } \\
(>200 \mathrm{ng} / \mathrm{ml})\end{array}$ \\
\hline Atopy & no data & no $A D$ & $12 / 33(38 \%)$ & $\begin{array}{l}4 / 26(17 \%) \\
\text { with AD }\end{array}$ & $\begin{array}{l}26 / 150(17 \%) \text { with } \\
\text { AD }\end{array}$ & $\begin{array}{l}2 / 47(4 \%) \\
\text { with AD at } \\
3 \text { months }\end{array}$ & $\begin{array}{l}\text { no IgE antibody to } \\
\text { common } \\
\text { aeroallergens }\end{array}$ \\
\hline $\begin{array}{l}\mathrm{FH} \\
\text { of atopy }\end{array}$ & $12 / 43(28 \%)$ & $\begin{array}{l}\text { no FH of } \\
\text { atopy }\end{array}$ & no data & no data & $63 / 150(42 \%)$ & $\begin{array}{l}27 / 47 \\
(57 \%)\end{array}$ & no data \\
\hline $\operatorname{IgE}$ & no data & no data & data not shown & $\begin{array}{l}3 / 22(14 \%) \\
\text { had total } \\
\text { serum IgE } \\
\geq 60 \mathrm{IU} / 1\end{array}$ & no data & $\begin{array}{l}\text { no data at } \\
\text { time of }\end{array}$ & total $\mathrm{IgE}=7 \mathrm{IU} / \mathrm{ml}$ \\
\hline $\begin{array}{l}\text { RSV-associated } \\
\text { recurrent wheezing }\end{array}$ & yes & no data & yes & no data & yes & yes & no data \\
\hline
\end{tabular}

Eos = Eosinophil; $\mathrm{AD}=$ atopic dermatitis $; \mathrm{FH}=$ family history.

'extrinsic') starting in childhood is the most widely studied, as it is the most common in real-life and easily studied in the clinical laboratory. In allergic asthma, the cytokine profile is predominantly Th2 (i.e. IL-4, IL-5, IL-9 and IL13). A recent genome microarray study by Woodruff et al. [93] found significant IL-13-mediated gene induction in asthma. One genetic biomarker in particular was associated with eosinophil accumulation in the airways, while another was identified as a potential mediator of corticosteroid-resistant asthma. Other studies, including the one by Martin et al. [94], have vetted other predictive markers, such as IgE and blood eosinophil levels, serum eosinophil degranulation protein levels, lung function and $\mathrm{PC}_{20}$ [95]. These examples highlight the need for careful consideration of phenotypes, especially variable treatment responses, when treating asthma patients.
The less common 'intrinsic' asthma is of late onset, lacks circulating specific IgE, and no sensitivities to allergens can be identified [38]; despite this, airway eosinophilia and Th2 cells feature prominently [96]. Intrinsic asthma is less common (approx. 10\%) than extrinsic asthma, is more common in females and tends to be more severe, requiring higher doses of corticosteroids [97]. However, clinically, intrinsic asthma shares a great deal with extrinsic asthma, including variable airflow obstruction and symptoms, and a good therapeutic response to corticosteroid therapy. It is well established that upper respiratory tract viral infections are the most common cause of exacerbations in intrinsic and extrinsic asthma [98].

In addition to eosinophilic inflammation, other cardinal features of most asthmatic phenotypes include airway hyperresponsiveness, excessive airway mucus production and airway remodeling [38]. 


\section{Eosinophils and Asthma}

Eosinophil increases in the tissues, body fluids (e.g., sputum, peripheral blood, serum, bronchoalveolar lavage) and bone marrow have been noted in asthma $[88,99,100]$. These elevated levels have correlated well with disease severity, leading to the hypothesis that eosinophils are the major effector cells of asthma. One way in which they act as major effector cells is through the release of granule proteins, which induce tissue damage and dysfunction [101], as well as the further propagation of airway inflammation. Elevated levels of ECP [102] and EDN [103] have been noted in asthmatics, with higher levels of ECP [104] and EDN [105] found during asthma exacerbation when compared with healthy patients and those with stable asthma. This would suggest that airway inflammation associated with asthma exacerbation is characterized not only by an increase in the number of eosinophils, but also by an increase in airway eosinophil degranulation [106].

\section{Monitoring of Asthma with Eosinophil Markers}

Though eosinophils are important in the pathophysiology of asthma, eosinophil degranulation and its associated products, such as EDN and ECP, may be even more important. It has been suggested that the secretory activity of eosinophils - a combination of the concentration of eosinophils and their propensity to release degranulation products - may be a key marker of disease activity and is more accurately measured by eosinophil degranulation products such as EDN and ECP [107]. Kim et al. [108] found significant differences in EDN and ECP levels in asthmatics during both acute and stable phases when compared with controls. Thus, EDN, along with ECP, may aid in the diagnosis of asthma. It has been suggested by several groups that EDN is more useful than ECP in evaluating disease severity [108-110]. This may partially be due to the recoverability of EDN, as ECP is a sticky and more highly charged protein [101].

In terms of clinical utility, EDN levels are a more accurate biomarker of the underlying pathophysiology of asthma (i.e. eosinophilic inflammation); consequently, they provide an objective measure of the secretory activity of eosinophils. In children too young to fully participate in lung function tests, EDN levels may be useful as an alternative measurement of eosinophilic inflammation, but larger studies should be carried out to determine the reproducibility and repeatability for this purpose.

Other Asthma Markers

Fractional exhaled concentration of nitric oxide (FeNO) has recently emerged as a biomarker to aid in the diagnosis, treatment and monitoring of asthma. Measurement of FeNO is relatively easy, and several devices are readily available and not too costly [111]. In a recently published study of children aged 5-18 years, FeNO compared favorably with sputum eosinophil percentage and better than spirometry for confirming asthma diagnosis [112]. However, obtaining FeNO was easier and less time consuming than obtaining induced sputum. One area of interest would be an investigation of FeNO levels during virus-induced asthma exacerbations versus those levels found in non-viral-induced (e.g., allergens) asthma exacerbations.

Knuffman et al. [113] recently found that an elevated baseline level of FeNO was predictive of a favorable response to inhaled corticosteroids. However, FeNO is limited in this area, as a substantial number of patients with lower FeNO may still respond to inhaled corticosteroid treatment [111].

A recent meta-analysis [114] of the study of Green et al. [115] and 2 others [116, 117] bolsters the hypothesis that treatment based on sputum eosinophil counts is more efficacious than treatment based on clinical symptoms and other traditional objective measures of lung function. However, serial methacholine challenge tests or sputum eosinophil measurements are time consuming, labor intensive and expensive. As a proposed alternative guide to anti-inflammatory treatment for asthma, FeNO has demonstrated little to no benefit [111]. Furthermore, in studies of asthma control, induced sputum eosinophils have consistently performed as well or better than FeNO [118].

\section{Conclusion}

Viral infections are important causes of childhood respiratory disease. They can lead to long-term morbidity, such as recurrent wheezing, and evidence points toward a very strong link between early childhood infection and asthma development. However, the underlying pathophysiologic link between infection and chronic allergic disease is still not fully understood. With increased understanding and attention to these disease processes, clinicians will better be able to diagnose, treat and monitor asthma. Indeed, the focus must shift from not only treating symptoms, but also the underlying pathophysiology, to provide optimal care to the patient. 


\section{References}

-1 Sigurs N, Gustafsson PM, Bjarnason R, Lundberg F, Schmidt S, Sigurbergsson F, Kjellman B: Severe respiratory syncytial virus bronchiolitis in infancy and asthma and allergy at age 13. Am J Respir Crit Care Med 2005;171:137-141.

$\checkmark 2$ Henderson J, Hilliard TN, Sherriff A, Stalker D, Al Shammari N, Thomas HM: Hospitalization for RSV bronchiolitis before 12 months of age and subsequent asthma, atopy and wheeze: a longitudinal birth cohort study. Pediatr Allergy Immunol 2005; 16: 386-392.

>3 Stein RT, Sherrill D, Morgan WJ, Holberg CJ, Halonen M, Taussig LM, Wright AL, Martinez FD: Respiratory syncytial virus in early life and risk of wheeze and allergy by age 13 years. Lancet 1999;354:541-545.

4 Kotaniemi-Syrjanen A, Vainionpaa R, Reijonen TM, Waris M, Korhonen K, Korppi M: Rhinovirus-induced wheezing in infancy the first sign of childhood asthma? J Allergy Clin Immunol 2003;111:66-71.

5 Martinez FD: Respiratory syncytial virus bronchiolitis and the pathogenesis of childhood asthma. Pediatr Infect Dis J 2003; 22:S76-S82.

-6 Wu P, Dupont WD, Griffin MR, Carroll KN, Mitchel EF, Gebretsadik T, Hartert TV: Evidence of a causal role of winter virus infection during infancy in early childhood asthma. Am J Respir Crit Care Med 2008;173: 1123-1129.

7 Martinez FD, Wright AL, Taussig LM, Holberg CJ, Halonen M, Morgan WJ: Asthma and wheezing in the first six years of life. $\mathrm{N}$ Engl J Med 1995;332:133-138.

8 Mcintosh K: Respiratory Syncytial Virus; in Kliegman RM, Behrman RE, Jenson HB, Stanton BF (eds): Nelson Textbook of Pediatrics, ed 18. Philadelphia, Saunders Elsevier, 2007, pp 1388-1390.

9 Wenzel SE, Gibbs RL, Lehr MV, Simoes EA: Respiratory outcomes in high-risk children 7 to 10 years after prophylaxis with respiratory syncytial virus immune globulin. Am J Med 2002;112:627-633.

-10 Simoes EA, Groothuis JR, Carbonell-Estrany X, Rieger CH, Mitchell I, Fredrick LM, Kimpen JL, Palivizumab Long-Term Respiratory Outcomes Study Group: Palivizumab prophylaxis, respiratory syncytial virus, and subsequent recurrent wheezing. J Pediatr 2007;151:34-42, 42.e1.

-11 Lemanske RF Jr: Viral infections and asthma inception. J Allergy Clin Immunol 2004;114: 1023-1026.

- 12 Lemanske RF Jr, Jackson DJ, Gangnon RE, Evans ME, Li Z, Shult PA, Kirk CJ, Reisdorf E, Roberg KA, Anderson EL, Carlson-Dakes KT, Adler KJ, Gilbertson-White S, Pappas TE, Dasilva DF, Tisler CJ, Gern JE: Rhinovirus illnesses during infancy predict subsequent childhood wheezing. J Allergy Clin Immunol 2005;116:571-577.
13 Miller EK, Lu X, Erdman DD, Poehling KA, Zhu Y, Griffin MR, Hartert TV, Anderson LJ Weinberg GA, Hall CB, Iwane MK, Edwards KM, New Vaccine Surveillance Network: Rhinovirus-associated hospitalizations in young children. J Infect Dis 2007;195:773781.

14 Johnston SL: Innate immunity in the pathogenesis of virus-induced asthma exacerbations. Proc Am Thorac Soc 2007;4:267-270.

15 Lee WM, Kiesner C, Pappas T, Lee I, Grindle K, Jartti T, Jakiela B, Lemanske RF, Shult PA Gern JE: A diverse group of previously unrecognized human rhinoviruses are common causes of respiratory illnesses in infants. PLoS One 2007;2:e966.

16 Korppi M, Kotaniemi-Syrjanen A, Waris M, Vainionpaa R, Reijonen TM: Rhinovirus-associated wheezing in infancy: comparison with respiratory syncytial virus bronchiolitis. Pediatr Infect Dis J 2004;23:995-999.

-17 Papadopoulos NG, Moustaki M, Tsolia M, Bossios A, Astra E, Prezerakou A, Gourgiotis D, Kafetzis D: Association of rhinovirus infection with increased disease severity in acute bronchiolitis. Am J Respir Crit Care Med 2002;165:1285-1289.

18 Kusel MM, de Klerk NH, Holt PG, Kebadze T, Johnston SL, Sly PD: Role of respiratory viruses in acute upper and lower respiratory tract illness in the first year of life: a birth cohort study. Pediatr Infect Dis J 2006;25: 680-686.

19 Jackson DJ, Gangnon RE, Evans MD, Roberg KA, Anderson EL, Pappas TE, Printz MC Lee WM, Shult PA, Reisdorf E, Carlson-Dakes KT, Salazar LP, DaSilva DF, Tisler CJ, Gern JE, Lemanske RF Jr: Wheezing rhinovirus illnesses in early life predict asthma development in high-risk children. Am J Respir Crit Care Med 2008;178:667-672.

20 Kusel MM, de Klerk NH, Kebadze T, Vohma V, Holt PG, Johnston SL, Sly PD: Early-life respiratory viral infections, atopic sensitization, and risk of subsequent development of persistent asthma. J Allergy Clin Immunol 2007;119:1105-1110.

-21 Message SD, Laza-Stanca V, Mallia P, Parker HL, Zhu J, Kebadze T, Contoli M, Sanderson G, Kon OM, Papi A, Jeffery PK, Stanciu LA, Johnston SL: Rhinovirus-induced lower respiratory illness is increased in asthma and related to virus load and Th1/2 cytokine and IL-10 production. Proc Natl Acad Sci USA 2008;105:13562-13567.

$\checkmark 22$ Allander T, Tammi MT, Eriksson M, Bjerkner A, Tiveljung-Lindell A, Andersson B: Cloning of a human parvovirus by molecular screening of respiratory tract samples. Proc Natl Acad Sci USA 2005;102: 12891-12896.

23 Allander T: Human bocavirus. J Clin Virol 2008;41:29-33.
24 Chung JY, Han TH, Kim SW, Kim CK, Hwang ES: Detection of viruses identified recently in children with acute wheezing. J Med Virol 2007;79:1238-1243.

25 Vallet C, Pons-Catalano C, Mandelcwajg A, Wang A, Raymond J, Lebon P, Gendrel D: Human bocavirus: a cause of severe asthma exacerbation in children. J Pediatr 2009;155: 286-288

26 Castro-Rodriguez JA, Holberg CJ, Wright AL, Halonen M, Taussig LM, Morgan WJ, Martinez FD: Association of radiologically ascertained pneumonia before age $3 \mathrm{yr}$ with asthmalike symptoms and pulmonary function during childhood: a prospective study. Am J Respir Crit Care Med 1999;159:18911897.

-27 Jartti T, van den Hoogen B, Garofalo RP, Osterhaus AD, Ruuskanen O: Metapneumovirus and acute wheezing in children. Lancet 2002;360:1393-1394.

28 Kim CK, Choi J, Callaway Z, Kim HB, Chung JY, Shin BM: Clinical and epidemiological comparison of human metapneumovirus and respiratory syncytial virus in Seoul, Korea, 2003-2008. J Korean Med Sci 2010;25: 342-347.

29 Nicholson KG, Kent J, Ireland DC: Respiratory viruses and exacerbations of asthma in adults. BMJ 1993;307:982-986.

30 Johnston SL, Pattemore PK, Sanderson G, Smith S, Lampe F, Josephs L, Symington P, O'Toole S, Myint SH, Tyrrell DA, Holgate ST: Community study of role of viral infections in exacerbations of asthma in 9-11 year old children. BMJ 1995;310:1225-1229.

-31 Rakes GP, Arruda E, Ingram JM, Hoover GE, Zambrano JC, Hayden FG, Platts-Mills TAE, Heymann PW: Rhinovirus and respiratory syncytial virus in wheezing children requiring emergency care. Am J Respir Crit Care Med 1999;159:785-790.

32 Leung TF, To MY, Yeung AC, Wong YS, Wong GW, Chan PK: Multiplex molecular detection of respiratory pathogens in children with asthma exacerbation. Chest 2010; 137:348-354.

-33 Atmar RL, Guy E, Guntupalli KK, Zimmerman JL, Bandi VD, Baxter BD, Greenberg SB: Respiratory tract viral infections in innercity asthmatic adults. Arch Intern Med 1998; 158:2453-2459.

-34 Green RM, Custovic A, Sanderson G, Hunter J, Johnston SL, Woodcock A: Synergism between allergens and viruses and risk of hospital admission with asthma: case-control study. BMJ 2002;324:763.

-35 Tarlo SM, Broder I, Corey P, Chan-Yeung M, Ferguson A, Becker A, Rogers C, Okada M, Manfreda J: The role of symptomatic colds in asthma exacerbations: influence of outdoor allergens and air pollutants. J Allergy Clin Immunol 2001;108:52-58. 
36 Papadopoulos NG, Velissariou I: The role of respiratory viruses in the pathogenesis of pediatric asthma. Pediatr Ann 2006;35:637642.

- 37 Papadopoulos NG, Xepapadaki P, Mallia P, Brusselle G, Watelet JB, Xatzipsalti M, Foteinos G, van Drunen CM, Fokkens WJ, D’Ambrosio C, Bonini S, Bossios A, Lotvall J, van Cauwenberge P, Holgate ST, Canonica GW, Szczeklik A, Rohde G, Kimpen J, Pitkaranta A, Makela M, Chanez P, Ring J, Johnston SL: Mechanisms of virus-induced asthma exacerbations: state-of-the-art. A GA2LEN and InterAirways document. Allergy 2007;62:457-470.

- 38 Hogan SP, Rosenberg HF, Moqbel R, Phipps S, Foster PS, Lacy P, Kay AB, Rothenberg ME: Eosinophils: biological properties and role in health and disease. Clin Exp Allergy 2008;38:709-750.

- 39 Arnold R, Humbert B, Werchau H, Gallati H, Konig W: Interleukin-8, interleukin-6, and soluble tumour necrosis factor receptor type I release from a human pulmonary epithelial cell line (A549) exposed to respiratory syncytial virus. Immunology 1994;82:126-133.

-40 Piliponsky A, Gleich G, Bar I, Levi-Schaffer F: Effects of eosinophils on mast cells: a new pathway for the perpetuation of allergic inflammation. Mol Immunol 2002;38:1369.

-41 Rosenberg HF, Dyer KD, Domachowske JB: Respiratory viruses and eosinophils: exploring the connections. Antiviral Res 2009;83: $1-9$.

42 Smith JA: Neutrophils, host defense, and inflammation: a double-edged sword. J Leukoc Biol 1994;56:672-686.

-43 Domachowske JB, Dyer KD, Bonville CA, Rosenberg HF: Recombinant human eosinophil-derived neurotoxin/RNase 2 functions as an effective antiviral agent against respiratory syncytial virus. J Infect Dis 1998;177: 1458-1464.

44 Rosenberg HF, Domachowske JB: Eosinophils, ribonucleases and host defense: solving the puzzle. Immunol Res 1999;20:261274 .

45 Rosenberg HF, Domachowske JB: Eosinophils, eosinophil ribonucleases, and their role in host defense against respiratory virus pathogens. J Leukoc Biol 2001;70:691-698.

-46 Milner JD, Ward JM, Keane-Myers A, Paul WE: Lymphopenic mice reconstituted with limited repertoire $\mathrm{T}$ cells develop severe, multiorgan Th2-associated inflammatory disease. Proc Natl Acad Sci USA 2007;104: 576-581.

47 Phipps S, Lam CE, Mahalingam S, Newhouse M, Ramirez R, Rosenberg HF, Foster PS, Matthaei KI: Eosinophils contribute to innate antiviral immunity and promote clearance of respiratory syncytial virus. Blood 2007;110:1578-1586.

48 Holgate ST: Has the time come to rethink the pathogenesis of asthma? Curr Opin Allergy Clin Immunol 2010;10:48-53.
49 Holgate ST, Davies DE, Lackie PM, Wilson SJ, Puddicombe SM, Lordan JL: Epithelialmesenchymal interactions in the pathogenesis of asthma. J Allergy Clin Immunol 2000; 105:193-204.

50 Holgate ST: Epithelium dysfunction in asthma. J Allergy Clin Immunol 2007;120:12331244.

51 Bucchieri F, Puddicombe SM, Lordan JL, Richter A, Buchanan D, Wilson SJ, Ward J, Zummo G, Howarth PH, Djukanovic R, Holgate ST, Davies DE: Asthmatic bronchial epithelium is more susceptible to oxidantinduced apoptosis. Am J Respir Cell Mol Biol 2002;27:179-185.

52 Wark PA, Johnston SL, Bucchieri F, Powell R, Puddicombe S, Laza-Stanca V, Holgate ST, Davies DE: Asthmatic bronchial epithelial cells have a deficient innate immune response to infection with rhinovirus. J Exp Med 2005;201:937-947.

53 Lopez-Souza N, Favoreto S, Wong H, Ward T, Yagi S, Schnurr D, Finbeiner WE, Dolganov GM, Widdicombe JH, Boushey HA, Avila PC: In vitro susceptibility to rhinovirus infection is greater for bronchial than for nasal airway epithelial cells in human subjects. J Allergy Clin Immunol 2009;123: 1384-1390.

54 Bochkov YA, Hanson KM, Keles S, Brockman-Schneider RA, Jarjour NN, Gern JE: Rhinovirus-induced modulation of gene expression in bronchial epithelial cells from subjects with asthma. Mucosal Immuno 2010;3:69-80.

55 DeMore JP, Weisshaar EH, Vrtis RF, Swenson CA, Evan MD, Morin A, Hazel E, Bork JA, Kakumanu S, Sorkness R, Busse WW, Gern JE: Similar colds in subjects with allergic asthma and nonatopic subjects after inoculation with rhinovirus-16. J Allergy Clin Immunol 2009;124:245-252, 252.e1-3.

56 Bufford JD, Gern JE: The hygiene hypothesis revisited. Immunol Allergy Clin North Am 2005;25:247-262.

57 Strachan DP: Hay fever, hygiene, and household size. BMJ 1989;299:125-160.

58 Oddy WH, de Klerk NH, Sly PD, Holt PG: The effects of respiratory infections, atopy, and breastfeeding on childhood asthma. Eur Respir J 2002;19:899-905.

59 Gern JE: Viral respiratory infection and the link to asthma. Pediatr Infect Dis J 2008; 27:S97-S103.

60 Schaub B, Lauener R, von Mutius E: The many faces of the hygiene hypothesis. J Allergy Clin Immunol 2006;117:969-977.

61 Liu AH: Endotoxin exposure in allergy and asthma: reconciling a paradox. J Allergy Clin Immunol 2002;109:379-392.

62 Gereda JE, Leung DY, Thatayatikom A, Streib JE, Price MR, Klinnert MD, Liu AH: Relation between house-dust endotoxin exposure, type $1 \mathrm{~T}$-cell development, and allergen sensitization in infants at high risk of asthma. Lancet 2000;355:1680-1683.
63 Brandenburg AH, Kleinjan A, van Het Land B, Moll HA, Timmerman HH, de Swart RL, Neijens HJ, Fokkens W, Osterhaus AD: Type 1-like immune response is found in children with respiratory syncytial virus infection regardless of clinical severity. J Med Virol 2000;62:267-277.

-64 Schaub B, Liu J, Hoppler S, Schleich I, Huehn J, Olek S, Wieczorek G, Illi S, von Mutius E: Maternal farm exposure modulates neonatal immune mechanisms through regulatory $\mathrm{T}$ cells. J Allergy Clin Immunol 2009;123:774782 .

65 Oddy WH, Holt PG, Sly PD, Read AW, Landau LI, Stanley FJ, Kendall GE, Burton PR: Association between breastfeeding and asthma in 6 year old children: findings of a prospective birth cohort study. BMJ 1999;319: 815-819.

66 Saarinen UM, Kajosaari M: Breastfeeding as prophylaxis against atopic disease: prospective follow-up study until 17 years old. Lancet 1995;346:1065-1069.

67 Sakamoto M, Ida S, Takishima T: Effect of influenza virus infection on allergic sensitization to aerosolized ovalbumin in mice. J Immunol 1984;132:2614-2617.

68 Pizzichini MM, Pizzichini E, Clelland L, Efthimiadis A, Pavord I, Dolovich J, Hargreave FE: Prednisone-dependent asthma: inflammatory indices in induced sputum. Eur Respir J 1999;13:15-21.

69 Jatakanon A, Lim S, Barnes PJ: Changes in sputum eosinophils predict loss of asthma control. Am J Respir Crit Care Med 2000; 161:64-72.

70 Wardlaw AJ, Brightling C, Green R, Woltmann G, Pavord I: Eosinophils in asthma and other allergic diseases. Br Med Bull 2000;56:985-1003.

71 Fanat AI, Thomson JV, Radford K, Nair P, Sehmi R: Human airway smooth muscle promotes eosinophil differentiation. Clin Exp Allergy 2009;39:1009-1117.

-72 Haldar P, Brightling CE, Hargadon B, Gupta S, Monteiro W, Sousa A, Marshall RP, Bradding P, Green RH, Wardlaw AJ, Pavord ID: Mepolizumab and exacerbations of refractory eosinophilic asthma. N Engl J Med 2009;360:973-984.

73 Nair P, Pizzichini MM, Kjarsgaard M, Inman MD, Efthimiadis A, Pizzichini E, Hargreave FE, O’Byrne PM: Mepolizumab for prednisone-dependent asthma with sputum eosinophilia. N Engl J Med 2009;360:985993.

74 Moqbel R, Lace P, Adamko DJ, Odemuyiwa SO: Biology of eosinophils; in Adkinson NF Jr, Bochner BS, Busse WW, Holgate ST, Lemanske RF Jr, Simons FER (eds): Allergy: Principles and Practice. St. Louis, Mosby, 2008, pp 295-310. 
75 Gleich GJ, Adolphson CR: The eosinophil and bronchial asthma: evidence for a critical role of eosinophils in pathophysiology; in Sanderson CJ (ed): Interleukin-5: from Molecular to Drug Target for Asthma. Lung Biology in Health and Disease. New York, Dekker, 1999, pp 1-37.

- 76 Gupta SK, Ross GD, Good RA, Siegal FP: Surface markers of human eosinophils. Blood 1976;48:755-763.

77 Ebisawa M, Schleimer RP, Bickel C, Bochner BS: Phenotyping of purified human peripheral blood eosinophils using the blind panel mAb; in Schlossman SF, Boumsel L, Gilks W, Harlan J, Kishimoto T, Morimoto C, Ritz J, Shaw S, Silverstein R, Springer T, Tedder T, Todd R (eds): Leukocyte Typing V: White Cell Differentiation Antigens. New York, Oxford University Press, 1995, pp 10361038 .

-78 Fujii M, Tanaka H, Abe S: Interferon-gamma up-regulates expression of cysteinyl leukotriene type 2 receptors on eosinophils in asthmatic patients. Chest 2005;128:3148-3155.

-79 Zinchuk O, Fukushima A, Zinchuk V, Fukata K, Ueno H: Direct action of platelet activating factor (PAF) induces eosinophil accumulation and enhances expression of PAF receptors in conjunctivitis. Mol Vis 2005;11: 114-123.

-80 Wang H, Tan X, Chang H, Huang W, Gonzalez-Crussi F, Hsueh W: Platelet-activating factor receptor mRNA is localized in eosinophils and epithelial cells in rat small intestine: regulation by dexamethasone and gut flora. Immunology 1999;97:447-454.

81 Walsh ER, August A: Eosinophils and allergic airway disease: there is more to the story. Trends Immunol 2010;31:39-44.

82 Wang HB, Ghiran I, Matthaei K, Weller PF: Airway eosinophils: allergic inflammation recruited professional antigen-presenting cells. J Immunol 2007;179:7585-7592.

-83 Duez C, Dakhama A, Tomkinson A, Marquillies $\mathrm{P}$, Balhorn A, Tonnel AB, Bratton DL, Gelfand EW: Migration and accumulation of eosinophils toward regional lymph nodes after airway allergen challenge. J Allergy Clin Immunol 2004;114:820-825.

-84 Welliver RC, Wong DT, Sun M, Middleton E Jr, Vaughan RS, Ogra PL: The development of respiratory syncytial virus-specific $\operatorname{IgE}$ and the release of histamine in nasopharyngeal secretions after infection. N Engl J Med 1981;305:841-846

85 Harrison AM Bonville CA, Rosenberg HF, Domachowske JB: Respiratory syncytial virus-induced chemokine expression in the lower airways: eosinophil recruitment and degranulation. Am J Respir Crit Care Med 1999;159:1918-1924.

-86 Wang SZ, Smith PK, Lovejoy M, Bowden JJ, Alpers JH, Forsyth KD: Shedding of L-selectin and PECAM-1 and upregulation of Mac1 and ICAM-1 on neutrophils in RSV bronchiolitis. Am J Physiol 1998;275:L983-L989.
87 Kim CK, Choi J, Kim HB, Callaway Z, Shin BM, Kim JT, Fujisawa T, Koh YY: A randomized intervention of montelukast for postbronchiolitis: effect on eosinophil degranulation. J Pediatr 2010;156:749-754.

88 Kim CK, Kim SW, Park CS, Kim BI, Kang H, Koh YY: Bronchoalveolar lavage cytokine profiles in acute asthma and acute bronchiolitis. J Allergy Clin Immunol 2003;112:6471.

89 Ehlenfield DR, Cameron K, Welliver RC: Eosinophilia at the time of Respiratory Syncytial Virus bronchiolitis predicts childhood reactive airway disease. Pediatrics 2000;105 79-83.

90 Piippo-Savolainen E, Remes S, Korppi M: Does blood eosinophilia in wheezing infants predict later asthma? A prospective 18-20 year follow-up. Allergy Asthma Proc 2007; 28:163-169.

91 Sigurs N, Bjarnason R, Sigurbergsson F, Kjellman B, Bjorksten B: Asthma and immunoglobulin $\mathrm{E}$ antibodies after respiratory syncytial virus bronchiolitis: a prospective cohort study with matched controls. Pediatrics 1995; $95: 500-505$

92 Frischer T, Halmerbauer G, Gartner C, Rath R, Tauber E, Schierl M, Koller DY, Urbanek R, Forster J, Kuhr J: Eosinophil-derived proteins in nasal lavage fluid of neonates of allergic parents and the development of respiratory symptoms during the first 6 months of life. Collaborative SPACE team. Study on the Prevention of Allergy in Children in Europe. Allergy 2000;55:773-777.

93 Woodruff PG, Boushey HA, Dolganov GM, Barker CS, Yang YH, Donnelly S: Genomewide profiling identifies epithelial cell genes associated with asthma and with treatment response to corticosteroids. Proc Natl Acad Sci USA 2007; 104:15858-15863.

$\$ 94$ Martin RJ, Szefler SJ, King TS, Kraft M, Boushey HA, Chinchilli VM, Craig TJ, DiMango EA, Deykin A, Fahy JV, Israel E, Lazarus SC, Lemanske RF Jr, Leone FT, Pesola GR, Peters SP, Sorkness CA, Szwejbka LA, Wechsler ME: The Predicting Response to Inhaled Corticosteroid Efficacy (PRICE) trial. J Allergy Clin Immunol 2007;119:7380.

95 Szefler SJ, Phillips BR, Martinez FD, Chinchilli VM, Lemanske RF, Strunk RC, Zeiger RS, Larsen G, Spahn JD, Bacharier LB, Bloomber GR, Guilbert TW, Heldt G, Morgan WJ, Moss MH, Sorkness CA, Taussig LM: Characterization of within-subject responses to fluticasone and montelukast in childhood asthma. J Allergy Clin Immunol 2005;115:233-242.

-96 Humbert M, Menz G, Ying S, Corrigan CJ, Robinson DS, Durhan SR, Kay AB: The immunopathology of extrinsic (atopic) and intrinsic (non-atopic) asthma: more similarities than differences. Immunol Today 1999; 20:528-533.
-97 Barnes PJ: Intrinsic asthma: not so different from allergic asthma but driven by superantigens? Clin Exp Allergy 2009;39:11451151.

98 Wark PA, Gibson PG: Asthma exacerbations. 3. Pathogenesis. Thorax 2006;61: 909-915

-99 Kim CK, Kim JT, Kang H, Yoo Y, Koh YY: Sputum eosinophilia in cough-variant asthma as a predictor of the subsequent development of classic asthma. Clin Exp Allergy 2003;33:1409-1414.

100 Koh YY, Kang H, Kim CK: Ratio of serum eosinophil cationic protein/blood eosinophil counts in children with asthma: comparison between acute exacerbation and clinical remission. Allergy Asthma Proc 2003:24:269-274

101 Gleich GJ, Adolphson CR: The eosinophilic leukocyte: structure and function. Adv Immunol 1986;39:177-253.

102 Kim CK, Kim SW, Kim YK, Kang H, Yu J, Yoo Y, Koh YY: Bronchoalveolar lavage eosinophil cationic protein and interluekin-8 levels in acute asthma and acute bronchiolitis. Clin Exp Allergy 2005;35:591-597.

103 Kim HB, Kim CK, Iijima K, Kobayashi T, Kita $\mathrm{H}$ : Protein microarray analysis in patients with asthma: elevation of the chemokine PARC/CCL18 in sputum. Chest 2009; 135:295-302.

104 Gibson PG, Woolley KL, Carty K, MurreeAllen K, Saltos N: Induced sputum eosinophil cationic protein (ECP) measurement in asthma and chronic obstructive airway disease (COAD). Clin Exp Allergy 1998;28: 1081-1088.

105 Morioka J, Kurosawa M, Inamura H, Nakagami R, Mizushima Y, Omura Y, Shibata M, Chihara J: Increased EDN/EPX in ongoing asthma. Allergy 2000;55:1203-1204.

106 Motojima S, Akutsu I, Fukuda T, Makino S, Takatsu K: Clinical significance of measuring levels of sputum and serum ECP and serum IL-5 in bronchial asthma. Allergy 1993;48:98-106.

107 Venge P: Monitoring the allergic inflammation. Allergy 2004;59:26-32.

108 Kim CK, Callaway Z, Fletcher R, Koh YY: Eosinophil-derived neurotoxin in childhood asthma: correlation with disease severity. J Asthma 2010;47:568-573.

109 Kim KW, Lee KE, Kim ES, Song TW, Sohn $\mathrm{MH}$, Kim KE: Serum eosinophil-derived neurotoxin (EDN) in diagnosis and evaluation of severity and bronchial hyperresponsiveness in childhood asthma. Lung 2007;185:97-103.

110 Taniuchi S, Chihara J, Kojima T, Yamamoto A, Sasai M, Kobayashi Y: Serum eosinophil derived neurotoxin may reflect more strongly disease severity in childhood atopic dermatitis than eosinophil cationic protein. J Dermatol Sci 2001;26:79-82.

111 Kercsmar C: Exhaled nitric oxide in the diagnosis and management of childhood asthma. Ther Adv Respir Dis 2010;4:71-82. 
-112 Sivan Y, Gadish T, Fireman E, Soferman R: The use of exhaled nitric oxide in the diagnosis of asthma in school children. J Pediatr 2009;155:211-216.

-113 Knuffman JE, Sorkness CA, Lemanske RF Jr, Mauger DT, Boehmer SJ, Martinez FD, Bacharier LB, Strunk RC, Szefler SJ, Zeiger RS, Taussig LM, Childhood Asthma Research and Education Network of the National Heart, Lung, and Blood Institute: Phenotypic predictors of long-term response to inhaled corticosteroid and leukotriene modifier therapies in pediatric asthma. J Allergy Clin Immunol 2009;123: 411-416.
114 Petsky HL, Kynaston JA, Turner C, Lin AM, Cates CJ, Lasserson TJ, Chang AB: Tailored interventions based on sputum eosinophils versus clinical symptoms for asthma in children and adults. Cochrane Database Syst Rev 2007;2:CD005603.

115 Green RH, Brightling CE, McKenna S, Hargadon $\mathrm{B}$, Parker $\mathrm{D}$, Bradding $\mathrm{P}$, Wardlaw AJ, Pavord ID: Asthma exacerbations and sputum eosinophil counts: a randomized controlled trial. Lancet 2002;360:17151721.

116 Chlumsky J, Striz I, Terl M, Vondracek J: Strategy aimed at reduction of sputum eosinophils decreases exacerbation rate in patients with asthma. J Int Med Res 2006;34: 129-139.
17 Jayaram L, Pizzichini MM, Cook RJ, Boulet LP, Lemiere C, Pizzichini E, Cartier A, Hussack P, Goldsmith CH, Laviolette M, Parameswaran K, Hargreave FE: Determining asthma treatment by monitoring sputum cell counts: effect on exacerbations. Eur Respir J 2006;27:483-494.

118 Zacharasiewicz A, Wilson N, Lex C, Erin EM, Li AM, Hansel T, Khan M, Bush A: Clinical use of noninvasive measurements of airway inflammation in steroid reduction in children. Am J Respir Crit Care Med 2005;171:1077-1082. 